\title{
UPAYA MENINGKATKAN AKTIVITAS DAN HASIL BELAJAR IPS PADA MATERI PELAKU KEGIATAN EKONOMI MELALUI PEMBELAJARAN CROSSWORD PUZZLE BAGI SISWA KELAS VIII- H SMP NEGERI 1 JATEN SEMESTER GENAP TAHUN PELAJARAN 2019/2020
}

\author{
Surtini Puji Hastuti ${ }^{\bowtie}$ \\ SMP Negeri 1 Jaten, Karanganyar
}

\begin{tabular}{l}
\hline Info Artikel \\
\hline Sejarah Artikel: \\
Disubmit: Mei 2021 \\
Direvisi : Mei 2021 \\
Diterima : Mei 2021 \\
\hline Keywords: \\
learning results; activities; \\
crossword puzzle; social \\
sciences
\end{tabular}

\begin{abstract}
Abstrak
Secara umum permasalahan yang ditemukan antara lain; model pembelajaran yang dilakukan oleh guru kurang tepat, dimana kegiatan pembelajaran dilakukan dengan dominasi ceramah secara keseluruhan. Berdasarkan nilai ulangan harian yang didapat ketuntasan kelas hanya $41 \%$. Oleh karena itu, penulis mencoba untuk mengatasi masalah tersebut dengan menerapkan model pembelajaran inovatif dengan model pembelajaran Crossword Puzzle, melalui penelitian tindakan kelas (PTK). Penelitian ini bertujuan untuk mendiskripsikan pelaksanaan pembelajaran menggunakan model pembelajaran Crossword Puzzle dapat peningkatan aktivitas dan hasil belajar siswa kelas VIII-H SMP Negeri 1 Jaten. Untuk itu rancangan penelitian ini menggunakan penelitian tindakan kelas. Subjek penelitian ini adalah siswa kelas VIII-H SMP Negeri 1Jaten Semester Genap tahun pelajaran 2019/2020 sebanyak 32 siswa. Data penelitian diperoleh dengan metode observasi dan tes. Hasil penelitian menunjukkan bahwa penggunaan pembelajaran model crossword puzzle dapat meningkatkan aktivitas dan hasil belajar siswa. Pada observasi awal nilai rata-rata hasil belajar siswa siklus I 72 dan siklus II 79. Hal ini menunjukkan bahwa penggunaan pendekatan kata konsep dapat meningkatkan kemampuan siswa.
\end{abstract}

Abstract

In general, the problems were found are; learning model done by the teacher are not appropriate, wherein learning activities was dominated by lecture during the class. Based on the daily test score, it was found that class completeness was only $41 \%$. Thus, the writer attempts to solve the problems by applying an innovative learning model specifically by using the Crossword Puzzle learning model through class action research (CAR / PTK in Indonesian). This research is aimed to describe the implementation of learning by using the Crossword Puzzle learning model to the enhancement of learning activities and results of the VIII-H students in SMP Negeri 1 Jaten. Therefore, the methodology of the research is class action research. The subject of the research is 32 students at VIIIH SMP Negeri 1 Jaten in the second-semester academic year 2019/2020. The data is collected by observation and test method. The result of this research shows that the use of the Crossword Puzzle learning model can improve students' learning activities and results. The average result of the observation specifically in the students' learning result on cycle I is 72 and cycle 2 is 79. This result shows that the implementation of the concept word approach can improve students' ability.

(C) 2021 Universitas Negeri Semarang

${ }^{\bowtie}$ Alamat korespondensi: ISSN 2252-7133

SMP Negeri 1 Jaten, Karanganyar

E-mail: surtinipuji1972@gmail.com

E-ISSN 2548-4648 


\section{PENDAHULUAN}

Peraturan Menteri Pendidikan Nasional Nomor 22 Tahun 2006 tentang standar isi untuk satuan pendidikan dasar dan menengah menyebutkan bahwa mata pelajaran Ilmu Pengetahuan Sosial (IPS) merupakan salah satu mata pelajaran yang diberikan mulai dari SD/MI/SDLB sampai SMP/MTs/SMPLB. Mata pelajaran IPS mengkaji seperangkat peristiwa, fakta, konsep, dan generalisasi yang berkaitan dengan isu sosial. Pada jenjang SD/MI mata pelajaran IPS memuat materi Geografi, Sejarah, Sosiologi, dan Ekonomi (Hidayati, 2008:3-8). Mata pelajaran IPS diberikan kepada semua peserta didik mulai dari sekolah dasar untuk membekali peserta didik dengan kemampuan berpikir logis, analitis, sistematis, kritis, dan bekerjasama.

Sekolah memiliki peranan dan tanggung jawab yang sangat penting dalam mempersiapkan warga negara yang memiliki komitmen kuat dan konsisten untuk mempertahankan Negara Kesatuan Republik Indonesia. Upaya yang dapat dilakukan adalah menyelenggarakan program pendidikan yang memberikan berbagai kemampuan sebagai seorang warga negara melalui berbagai mata pelajaran.

Dalam pelaksanaan pembelajaran IPS di lapangan, masih ada sebagian guru yang mengalami hambatan dan kesulitan dalam menerapkan kondisi yang dapat merangsang serta mengarahkan proses belajar peserta didik untuk memperoleh pengetahuan, sikap, keterampilan yang mengakibatkan perubahan perilaku maupun pertumbuhan pribadi peserta didik. Pembelajaran IPS tidak bisa dipelajari hanya dengan membaca teks atau mendengarkan ceramah saja tetapi harus dikembangkan atau ditemukan melalui suatu kerja ilmiah, serta proses pengajarannya harus mampu membina pembentukan kepribadian anak secara utuh, yaitu yang mencakup pembinaan pengembangan potensi kognitif, afektif, dan psikomotor anak didik.
Menurut Tim Sosialisasi Kurikulum Tingkat Satuan Pendidikan (KTSP) tahun 2006 bahwa pembelajaran IPS dewasa ini masih ketinggalan karena masih bersifat hafalan dan kurang mengembangkan proses berpikir, keterampilan proses dan sikap yang bisa dilatihkan melalui pembelajaran IPS juga kurang dikembangkan. Hal ini terjadi karena model pembelajaran yang diterapkan masih didasarkan pada asumsi keliru para guru yang menganggap pengetahuan dapat dipindahkan secara utuh dari pikiran pendidik kepada pikiran peserta didik.

Selain itu yang selama ini menjadi hambatan dalam pembelajaran Ilmu Pengetahuan Sosial adalah disebabkan kurang dikemasnya pembelajaran Ilmu Pengetahuan Sosial dengan metode yang menarik, sehingga pembelajaran Ilmu Pengetahuan Sosial cenderung membosankan dan kurang menarik minat para siswa yang pada gilirannya hasil belajar dan aktivitas siswa kurang memuaskan. Di sisi lain juga ada kecendrungan bahwa aktivitas siswa masih rendah hal ini disebabkan bahwa pembelajaran Ilmu Pengetahuan Sosial dianggap sebagai suatu kegiatan yang membosankan, kurang menantang, tidak bermakna serta kurang terkait dengan kehidupan sehari-hari, akibatnya dalam pembelajaran IPS rendahnya daya kreasi guru dan siswa dalam pembelajaran, kurang dikuasainya materi-materi Ilmu Pengetahuan Sosial oleh siswa, dan kurangnya variasi dalam pembelajaran.

Pendidikan IPS pada jenjang pendidikan dasar mempunyai peranan yang sangat penting sebab jenjang ini merupakan pondasi yang sangat menentukan dalam membentuk sikap, kecerdasan dan kepribadian anak. Namun kenyataan menunjukkan banyaknya keluhan dari siswa tentang pelajaran IPS yang tidak menarik dan membosankan. Keluhan ini secara langsung atau tidak langsung akan sangat berpengaruh terhadap prestasi belajar IPS pada setiap jenjang pendidikan. Meskipun upaya mengatasi hasil belajar IPS yang rendah telah dilakukan oleh pemerintah. Seperti penyempurnaan kurikulum, pengadaan buku 
paket, peningkatan pengetahuan guru-guru melalui sertifikasi, serta melakukan berbagai penelitian terhadap faktor-faktor yang diduga mempengaruhi hasil belajar IPS. Namun kenyataan menunjukkan bahwa hasil belajar IPS masih jauh dari yang diharapkan.

Menghadapi permasalahan seperti di atas tentu bukan pekerjaan yang mudah bagi guru untuk memilih metode pembelajaran. Kearifan, pengalaman, dan kreativitas mutlak diperlukan bagi seorang guru untuk membantu peserta didik dalam rangka memecahkan kesulitan yang dihadapi. Berpijak dari permasalahan yang melatarbelakangi, peneliti mencoba menggunakan metode pembelajaran kooperatif tipe kata konsep pada mata pelajaran IPS di Kelas VIII-H SMP Negeri 1 Jaten. Media pembelajaran ini memfasilitasi peserta didik untuk mengembangkan kegembiraan dalam proses belajar mengajar, mampu menghilangkan sifat egoisme peserta didik. Suasana yang menyenangkan diharapkan juga tercipta melalui penggunaan metode pembelajaran kata konsep yang menarik. Dengan adanya inovasi pembelajaran yang menyenangkan ini diharapkan hasil belajar peserta didik meningkat. Dengan mencermati hal tersebut dapat diketahui bahwa hasil belajar siswa juga dipenaruhi oleh penggunaan model yang tepat.

Penelitian ini bertujuan untuk mengetahui penerapan pembelajaran crossword puzzle dapat meningkatkan aktivitas pada pembelajaran IPS materi Pelaku Kegiatan Ekonomi pada Siswa Kelas VIII-H Semester Genap SMP Negeri 1 Jaten Tahun Pelajaran 2019/ 2020. Kemudian untuk mengetahui penerapan pembelajaran crossword puzzle dapat meningkatkan Hasil Belajar pada pembelajaran IPS materi Pelaku Kegiatan Ekonomi pada Siswa Kelas VIII-H Semester Genap SMP Negeri 1 Jaten Tahun Pelajaran 2019/ 2020.

\section{METODE}

Pelaksanaan penelitian ini menggunakan jenis Penelitian Tindakan Kelas (PTK). Penelitian ini diawali dengan melakukan melakukan identifikasi terhadap masalah awal terhadap rendahnya tingkat partisipasi dan hasil belajar siswa kelas VIII-H SMP Negeri 1 Jaten, semester genap tahun pelajaran 2019/2020.

Berdasarkan pengamatan awal yang ditemukan penyebab rendahnya tingkat partisipasi dan hasil belajar siswa kelas VIII-H SMP Negeri 1 Jaten, adalah penggunaan pendekatan pembelajaran yang tidak mampu membawa siswa ke dalam situasi yang nyata dan menyenangkan. Akibatnya, proses pembelajaran berlangsung monoton dan membosankan. Oleh karena itu, diperlukan pendekatan pembelajaran yang diduga mampu membawa siswa ke dalam situasi secara nyata sehingga siswa memperoleh manfaat praktis dalam peristiwa sehari-hari.

Subjek utama dalam penelitian adalah siswa kelas VIII-H SMP Negeri 1 Jaten Semester Genap tahun pelajaran 2019/2020. Peneliti memilih kelas VIII-H sebagai subjek penelitian karena siswa di kelas ini heterogen. Di kelas ini terdapat siswa yang berkemampuan kurang, sedang, dan baik.

Sumber data primer, yaitu sumber data dari siswa langsung yang berupa data nilai ulangan harian kelas VIII-H SMP Negeri 1 Jaten semester genap tahun pelajaran 2019/2020. Kemudian sumber data sekunder, yaitu sumber data dari peneliti yang dibantu oleh teman sejawat yang berupa hasil pengamatan peneliti terhadap siswa di kelas VIII-H.

Sejalan dengan data yang akan dukumpulkan serta sumber data yang dibutuhkan dalam penelitian, selanjutnya akan dilakukan teknik tata cara pengumpulan data diatas yang meliputi antara lain yaitu: pengamatan, wawancara atau diskusi, kajian dokumen, angket dan tes. 
Teknik validasi data, pada data kuantitatif divalidasi dalam hal ini adalah butir soal yangdisusun berdasarkan kisi-kisi soal agar memenuhi validitas teoritis dan content/isi. Sedangkan pada data kualitatif menggunakan observasi dan wawancara, yang divalidasi melalui trianggulasi.

Data penelitian dianalisis dengan menggunakan teknik tabulasi data secara kualitatif berdasarkan hasil tindakan yang dilaksanakan pada setiap siklus. Hasil tindakan pada setiap siklus dibandingkan dengan hasil tes awal untuk mengetahui persentase peningkatan hasil belajar siswa kelas VIII-H SMP Negeri 1 Jaten Semester Genap tahun pelajaran 2019/2020.

\section{HASIL DAN PEMB AHASAN Diskripsi Kondisi Awal}

Data pra siklus merupakan data yang diambil dari hasil pengamatan terhadap pembelajaran IPS, baik berupa catatan lapangan mengenai pembelajaran IPS, data hasil belajar siswa, maupun data dokumen dari hasil evaluasi belajar siswa yang berhubungan dengan pembelajaran IPS di kelas. Data tersebut kemudian dianalisis bersama dengan guru kolaborator, dan dari data tersebut ditemukan permasalahan mengenai pembelajaran IPS di kelas VIII-H.

Dari hasil identifikasi bersama guru kolabolator, penyebab permasalahan di atas dipengaruhi oleh beberapa faktor, antara lain guru dalam melaksanakan kegiatan pembelajaran belum optimal. Keterampilan penggunaan variasi pembelajaran yang dilaksanakan guru masih belum mengacu pada berbagai model pembelajaran yang sudah ada. Pemanfaatan media pembelajaran pun belum optimal.

Karena kurangnya variasi dalam
pemanfaatan metode pembelajaran yang
inovatif dan menyenangkan maka hasil belajar
IPS menjadi rendah. Demikian pula yang
dialami peserta didik kelas VIII-H SMP Negeri 1

Jaten, nilai pemahaman dan penguasaan materi masih rendah dan belum mencapai tuntas belajar. Hal ini terlihat pada hasil belajar pada ulangan harian pada materi sebelumnya nilai rata-rata ulangan harian: 70 dengan persentase peserta yang tuntas belajar sebesar $41 \%$. Deskripsi data hasil belajar siswa pra siklus dapat dinyatakan dalam tabel berikut ini:

Tabel 1 Data Rekap Nilai Ulangan Harian Kondisi Awal

\begin{tabular}{lll}
\hline No. & Pencapaian & Hasil \\
\hline 1 & Nilai terendah & 52 \\
2 & Nilai tertinggi & 88 \\
3 & Jumlah siswa tuntas & 13 \\
4 & Jumlah siswa tidak tuntas & 19 \\
5 & Persentase ketidaktuntasan & $59 \%$ \\
6 & Presentase ketuntasan & $41 \%$ \\
7 & Rata-rata & 70 \\
\hline \multicolumn{2}{l}{ Sumber: penelitian 2020 }
\end{tabular}

Berdasarkan tabel 1 tersebut dapat dikemukakan bahwa pada awal kondisi sebelum diterapkan metode pembelajaran crossword puzzle diterapkan sebagian besar siswa (sebesar 59\%) belum memenuhi nilai KKM. Hal tersebut tentu saja masih dibawah harapan dari guru. Rata-rata kelas secara klasikal tidak memenuhi syarat minimal KKM yaitu hanya sebesar 70 . Ketuntasan yang dicapai setelah evaluasi pada tahap ini adalah sebanyak 13 siswa atau sebesar $41 \%$. Sementara itu sisanya sebanyak 19 siswa atau sebesar $59 \%$ belum memenuhi nilai KKM yang ditentukan yaitu dibawah 70 .

Berdasarkan permasalahan yang telah peneliti paparkan di atas maka peneliti dan tim kolaborator melaksanakan penelitian tindakan kelas dengan menerapkan pembelajaran dengan crossword puzzle di kelas VIII-H SMP Negeri 1 Jaten untuk menyelesaikan permasalahan tersebut. 


\section{Deskripsi Siklus I}

\section{Perencanaan Tindakan}

Pelaksanaan tindakan siklus I pertemuan I dilaksanakan pada bulan Januari 2019. Pelaksanaan tindakan dilaksanakan dengan menerapkan pembelajaran crossword puzzle pada pembelajaran IPS dengan materi Pelaku Kegiatan Ekonomi.

\section{Pelaksanaan Tindakan}

Kegiatan pada pelaksanaan siklus meliputi pra kegiatan, kegiatan awal, kegiatan inti, dan penutup. Adapun paparan mengenai kegiatan pembelajaran adalah sebagai berikut:

Pra kegiatan

Kegiatan pendahuluan dilakukan guru dengan memberikan apersepsi yaitu siswa diajak tanya jawab mengenai materi yang akan dibahas. Guru memberikan pertanyaan apersepsi kepada siswa yang akan terhubung dengan materi yang akan diajarkan. Guru menginformasikan tujuan pembelajaran yang akan dicapai pada kegiatan tersebut.

\section{Kegiatan Inti}

Kegiatan inti berlangsung yakni pertama-tama guru membagi kelompok secara heterogen. Guru membagi kelas menjadi 6 kelompok kecil dan setiap kelompoknya beranggotakan 3-4 siswa. Setiap kelompok diberikan tugas yang terbagi dalam segmen tugas yang harus diselesaikan oleh kelompok tersebut.

Kegiatan selanjutnya guru membagikan lembar kerja berupa crossword puzzle sebagai bahan untuk didiskusikan siswa dengan kelompok masing-masing. Guru membimbing jalannya diskusi dengan membimbing siswa yang mengalami kesulitan dalam mengerjakan dan memotivasinya untuk segera menyelesaikan lembar kerja.

Kegiatan berikutnya, guru meminta satu kelompok untuk mempresentasikan kerja kelompoknya di dalam kelas. Sementara itu kelompok lain memperhatikan dan memberikan catatan-catatan terhadap kelompok yang mempresentasikan hasil diskusi mereka. Setelah selesai guru menanggapi hasil presentasi kelompok dan memberikan penguatan pada siswa dengan penguatan verbal dan gestural. Penguatan verbal berupa pujian kepada individu dan kelompok. Penguatan gestural berupa pemberian tepuk tangan untuk kelompok yang mempresentasikan hasil diskusi kelompoknya serta memberikan reward bagi siswa yang sudah melaksanakan presentasi. Kegiatan tersebut berulang sampai semua kelompok selesai presentasi.

\section{Kegiatan Akhir (Penutup)}

Kegiatan penutup dilakukan oleh guru bersama siswa dengan menarik kesimpulan dari materi pelajaran yang telah dipelajari bersama-sama, yaitu mendata dan mengumpulkan informasi yang telah disusun berdasarkan model crossword puzzle. Setelah itu guru membagikan soal evaluasi pada siswa dan mengawasi jalannya tes. Siswa yang sudah selesai mengerjakan mengumpulkan hasil pekerjaanya. Kegiatan terakhir guru menyampaikan tentang materi berikutnya dan mengucapkan salam penutup kemudian mengakhiri pelajaran.

\section{Hasil Pengamatan}

Bersama dengan observer sebagai teman sejawat melakukan seluruh pengamatan dan dicatat dalam instrumen yang sudah disiapkan sebelumnya.

Tingkat pemahaman konsep peserta didik terhadap materi pembelajaran pada siklus I menunjukkan perubahan yang signifikan bila dibandingkan dengan kondisi awal peserta didik, dari hasil ulangan siklus I diketahui bahwa nilai rata-rata peserta didik mencapai 72 dengan persentase peserta didik yang tuntas belajar $62 \%$ atau sebanyak 20 siswa telah mencapai nilai KKM. 
Data mengenai hasil belajar kognitif siswa diperoleh dari hasil analisis nilai evaluasi hasil belajar siswa yang dilaksanakan di akhir siklus I.

Tabel 2 Data Rekap Nilai Ulangan Harian Siklus I

\begin{tabular}{lll}
\hline No. & Pencapaian & Hasil \\
\hline 1 & Nilai terendah & 52 \\
2 & Nilai tertinggi & 88 \\
3 & Jumlah siswa tuntas & 20 \\
4 & Jumlah siswa tidak tuntas & 12 \\
5 & Persentase ketidaktuntasan & 38 \\
6 & Presentase ketuntasan & 62 \\
7 & Rata-rata & 72 \\
\hline
\end{tabular}

Sumber: penelitian 2020

Berdasarkan tabel 2 tersebut dapat digambarkan dalam grafik berikut ini:

Grafik 1 Ketuntasan Nilai Ulangan Harian Siklus 1

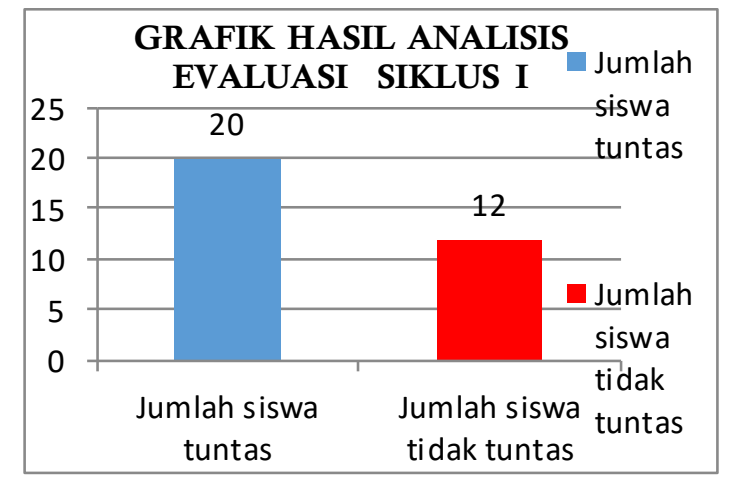

Sumber: penelitian 2020

Berdasarkan tabel 2 tersebut nilai ketuntasan klasikal mencapai $62 \%$ dengan rata-rata perolehan sebesar 72 . Sebanyak 20 siswa telah mencapai nilai ketuntasan minimal. Nilai tertinggi siswa aktif mencapai angka 88 .

Selain data hasil pengamatan terhadap hasil belajar, peneliti juga melakukan observasi terhadap partisipasi yang dilakukan oleh siswa selama proses pembelajaran dalam kelompok berlangsung.sesuai dengan tujuan penelitian ini yaitu untuk mengetahui peningkatan aktivitas siswa. Berdasarkan pengamatan terhadap aktivitas siswa dapat kita lihat dalam tabel berikut:

Tabel 3 Data Hasil Pengamatan Prilaku / Keaktifan Kegiatan Belajar Siswa Siklus 1

\begin{tabular}{llcc}
\hline No & $\begin{array}{c}\text { Kegiatan yang } \\
\text { diamati }\end{array}$ & \multicolumn{2}{c}{$\begin{array}{c}\text { Prilaku/keaktifan } \\
\text { Siswa }\end{array}$} \\
\cline { 3 - 4 } & & Jumlah & $\%$ \\
& & 20 & 59 \\
$\mathbf{1}$ & Perhatian siswa & 8 & 24 \\
$\mathbf{2}$ & Kemampuan & 16 & 47 \\
$\mathbf{3}$ & bertanya & 17 & 50 \\
$\mathbf{4}$ & Kemampuan & & \\
& menjawab & & \\
& Rasa tanggung & & \\
\multicolumn{2}{l}{ jawab } \\
Sumber: penelitian 2020
\end{tabular}

Sumber: penelitian 2020

Berdasarkan tabel 3 tersebut dapat dilihat bahwa siswa yang secara aktif dapat menyesuaikan diri dalam metode pembelajaran yang diterapkan oleh guru secara langsung sebanyak 20 siswa atau baru sebesar $59 \%$ dari seluruh siswa didalam kelas. Hal ini tentu saja masih jauh dibawah harapan indikator keberhasilan yang diinginkan oleh peneliti.

Refleksi

Setelah dilakukan refleksi berdasarkan hasil pengamatan, melalui diskusi antara peneliti dan observer disimpulkan bahwa kinerja peneliti pada siklus I perlu ditingkatkan. Peneliti perlu memperbaiki perilaku guru terutama dalam pengelolaan kelas serta memberi penguatan dan penghargaan dalam pembelajaran pada siklus II.

\section{Deskripsi Siklus II}

\section{Perencanaan Tindakan}

Perencanaan tindakan yang dilakukan pada siklus II merupakan perbaikan rencana tindakan pada siklus I. Direncanakan peneliti lebih banyak dalam memberikan bimbingan kelompok bekerja, pengelolaan kelas serta memberi penguatan dan penghargaan dalam pembelajaran. 


\section{Pelaksanaan Tindakan}

Tindakan yang dilakukan telah mendekati perencanaan tindakan yang dibuat. Materi pembelajaran yang disajikan pada siklus II meneruskan apa yang telah dipelajari pertemuan sebelumnya damun masih dalam pokok bahasan yang sama. Diawal pembelajaran peneliti mereview tugas yang diberikan pada siklus sebelumnya, memberi apersepsi, motivasi dan menyampaikan tujuan pembelajaran, setelah itu memberi penjelasan tentang obyek deskripsi dan membagi peserta didik menjadi beberapa kelompok belajar, setelah itu meminta peserta didik sebagai perwakilan kelompok mempresentasikannya.

\section{Hasil Pengamatan}

Pembelajaran yang dilakukan mengalami peningkatan. Guru cukup baik dalam pengelolaan kelas, sehingga peserta didik yang ramai sendiri, berkurang. Tingkat pemahaman konsep peserta didik terhadap materi pembelajaran pada siklus II menunjukkan perubahan yang signifikan bila dibandingkan dengan Siklus I.

Tabel 4 Data Rekap Nilai Ulangan Harian Siklus 2

\begin{tabular}{lll}
\hline No. & Pencapaian & Hasil \\
\hline 1 & Nilai terendah & 67 \\
2 & Nilai tertinggi & 100 \\
3 & Jumlah siswa tuntas & 25 \\
4 & Jumlah siswa tidak tuntas & 7 \\
5 & Persentase ketidaktuntasan & 12 \\
6 & Presentase ketuntasan & 78 \\
7 & Rata-rata & 79 \\
\hline
\end{tabular}

Sumber: penelitian 2020.

Berdasarkan tabel 4 tersebut dapat digambarkan dalam grafik berikut ini :
Grafik 2 Hasil Analisis Evaluasi Siklus II

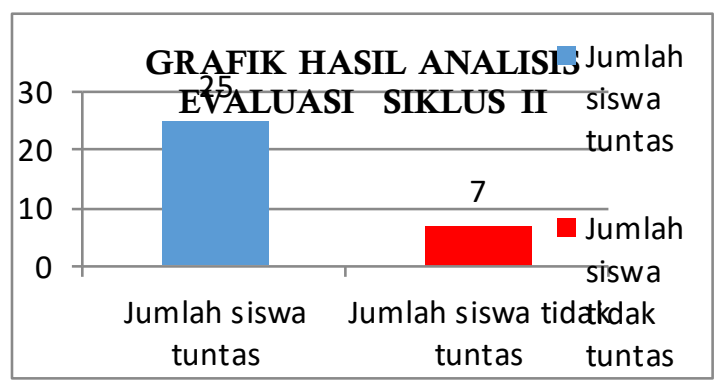

Sumber: penelitian 2020

Berdasarkan tabel tersebut dapat disimpulkan bahwa peningkatan hasil evaluasi belajar siswa terlihat pada jumlah siswa yang memperoleh nilai diatas 73 sebagai batas KKM sebanyak 25 siswa. Ketuntasn klasikal sudah memenuhi indikator keberhasilan yang ditetapkan sebelum penelitian yaitu tercapainya ketuntasan minimal sebesar 70\%.

Sementara itu pengamatan terhadap aktivitas siswa pada siklus II dapat digambarkan dalam tabel 5 ini :

Tabel 5 Data Hasil Pengamatan Prilaku / Keaktifan Kegiatan Belajar Siswa Siklus 2

\begin{tabular}{llcc}
\hline & \multicolumn{1}{c}{$\begin{array}{c}\text { Kegiatan yang } \\
\text { diamati }\end{array}$} & \multicolumn{2}{c}{$\begin{array}{c}\text { Prilaku/keaktifan } \\
\text { Siswa }\end{array}$} \\
\cline { 3 - 4 } & & Jumlah & $\%$ \\
$\mathbf{1}$ & & & \\
$\mathbf{2}$ & Perhatian siswa & 26 & 76 \\
$\mathbf{3}$ & Kemampuan & 22 & 65 \\
& bertanya & 23 & 68 \\
& Kemampuan & 28 & 82 \\
& menjawab & & \\
& Rasa tanggung & & \\
jawab & & \\
\hline
\end{tabular}

Sumber: penelitian 2020.

Berdasarkan tabel 5 tersebut dapat ditarik fakta bahwa kegiatan dalam kelompok yang dilakukan di dalam kelas mampu menarik perhatian siswa. Sebanyak 26 siswa atau sebesar $76 \%$ siswa tampak perhatian atau terlibat secara aktif pada kegiatan pragmatik yang dilakukan dalam kelompoknya. Hal ini disebabkan antara lain karena keinginan siswa 
untuk membuat presentasi kelompok mereka menjadi presentasi yang terbaik di dalam kelas. Tentu saja dengan keadaan tersebut memacu siswa dalam kelompok tersebut untuk terlibat secara penuh. Sebanyak 22 siswa atau sebanyak $65 \%$ siswa mendominasi kelompoknya sehingga terlihat sangat antusias. Dalam hal ini tampak ekspresi yang diperlihatkan mereka secara sungguh-sungguh memerankan tokoh dalam peran mereka secara tegas.

\section{Refleksi}

Secara umum peneliti melakukan proses pembelajaran lebih baik daripada siklus II, suasana kelas tampak hidup, sebagian besar peserta didik terlibat aktif dalam mengikuti proses pembelajaran terutama pada saat kegiatan dalam menyelesaikan tugas dalam kelompok, dalam mempresentasikan hasil kegiatan kelompok, sebagian peserta didik sudah mulai berani mempresentasikan tugas yang diberikan dengan kualitas yang meningkat. Tingkat pemahaman peserta didik terhadap materi pembelajaran pada siklus II menunjukkan perubahan yang signifikan bila dibandingkan dengan siklus I.

Memperhatikan data hasil pengamatan kinerja peneliti pada siklus II. Peneliti dan observer melakukan refleksi dengan cara mendiskusikan tentang tindakan penelitian yang akan dilakukan pada siklus III. Namun dari hasil diskusi disimpulkan bahwa kemampuan peserta didik dalam memahami materi dirasa cukup hal ini terlihat sudah sebagian peserta didik yang benar. Secara umum refleksi yang dilakukan antara peneliti dan observer melalui diskusi hasil pengamatan dan temuan pada siklus II adalah adanya usaha peneliti untuk meningkatkan pemahaman mengenai kemampuan menguasai materi berdampak meningkatnya hasil belajar peserta didik. Maka peneliti tidak merencanakan kegiatan pada siklus berikutnya.

\section{Pembahasan}

\section{Pembahasan Prasiklus}

Kondisi siswa pada pembelajaran prasiklus kurang mendukung. Pada pembelajaran prasiklus nilai rata-rata siswa adalah 70 dengan penjelasan siswa yang tuntas atau mencapai KKM sebanyak 13 siswa atau $41 \%$ dari jumlah siswa 32 orang. Nilai KKM yang harus dicapai siswa adalah 73. Dengan demikian, pada pembelajaran prasiklus masih terdapat 19 siswa yang belum tuntas atau $59 \%$.

Rincian selengkapnya tentang hasil pada prasiklus adalah sebagai berikut; siswa yang memperoleh nilai dengan rentang dibawah 70 sebanyak 12 siswa. Siswa yang memperoleh nilai dengan rentang 70 s.d. 100 sebanyak 15 siswa. Terdapat 13 siswa yang memperoleh nilai dengan rentang diatas 73 .

\section{Pembahasan Siklus I}

Setelah mengetahui hasil pembelajaran pada prasiklus, peneliti melakukan refleksi dan diskusi dengan teman observer. Diskusi membahas tentang penyebab kegagalan pembelajaran pada prasiklus. Masalah yang harus diatasi pada pembelajaran prasiklus, adalah masalah dari siswa, masalah dari guru, dan masalah yang berkaitan dengan metode pembelajaran.

Peneliti melakukan refleksi pada akhir pembelajaran prasiklus. Peneliti segera melakukan perubahan teknik atau metode pembelajaran pada siklus I. Hasil pembelajaran pada akhir siklus 1 ditemukan meningkat. Pada siklus I ini dari 32 siswa, yang dapat mencapai nilai KKM sebanyak 20 siswa. Persentase nilai siswa yang tuntas mengalami peningkatan sebesar $21 \%$. Pada awal kondisi terdapat $41 \%$ siswa saja meningkat menjadi sebesar $62 \%$. Sedangkan siswa yang nilainya belum tuntas menurun jumlahnya menjadi 12 orang atau 38 $\%$ siswa yang harus dituntaskan hasil belajarnya.

Untuk mengetahui perbandingan hasil pembelajaran yang meliputi nilai siswa dan persentase ketuntasan hasil belajar siswa, 
berikut ini peneliti akan menyajikan sebuah tabel.

Tabel 6 Perbandingan Nilai Ulangan Harian Siswa dan Ketuntasan Belajar Siswa Kondisi Awal/ Pra Siklus dan Siklus 1

\begin{tabular}{|c|c|c|c|c|}
\hline No & $\begin{array}{l}\text { Rentang } \\
\text { Nilai }\end{array}$ & $\begin{array}{l}\text { Fre } \\
\text { kue } \\
\text { nsi } \\
\text { Pra } \\
\text { Sikl } \\
\text { us }\end{array}$ & $\begin{array}{l}\text { Frek } \\
\text { uensi } \\
\text { Siklu } \\
\text { s I }\end{array}$ & $\begin{array}{l}\text { Selisi } \\
\mathrm{h}\end{array}$ \\
\hline 1 & dibawah 60 & 2 & 0 & 2 \\
\hline 2 & 60 s.d. 69 & 15 & 10 & 5 \\
\hline 3 & 70 s.d. 79 & 7 & 12 & 5 \\
\hline 4 & 80 s.d. 89 & 8 & 8 & 0 \\
\hline 5 & 90 s.d. 100 & 0 & 0 & 0 \\
\hline 6 & Jumlah nilai & 2252 & 2312 & 60 \\
\hline 7 & Rata-rata & 70 & 72 & 2 \\
\hline 8 & KKM & 73 & 73 & - \\
\hline 9 & Tuntas & 13 & 20 & 7 \\
\hline 10 & Tidak tuntas & 19 & 12 & 7 \\
\hline
\end{tabular}

Sumber: penelitian 2020

\section{Pembahasan Siklus II}

Siklus II merupakan siklus terakhir dalam penelitian ini. Peneliti merencanakan pelaksanaan penelitian tindakan kelas (PTK) ini sebanyak II siklus. Kegiatan dimulai dari pembelajaran prasiklus, diteruskan pengambilan tindakan pada Siklus I, dan finalnya, yaitu tindakan pada Siklus II atau siklus terakhir. Setelah akhir pembelajaran Siklus I, peneliti dan observer melakukan diskusi dan refleksi. Hasil analisis terhadap nilai siswa dan observasi pada Siklus I dijadikan acuan untuk pengambilan tindakan pada Siklus II .

Pada Siklus II ini, peneliti masih tetap menggunakan skenario pembelajaran seperti pada Siklus I , karena pada Siklus I hasil pembelajaran sudah menunjukkan peningkatan yang signifikan. Peningkatan itu bukan hanya pada rata-rata nilai siswa tetapi juga pada persentase ketuntasan nilai siswa. Pada Siklus II ini pembelajaran berjalan lebih lancar. Para siswa sudah terkondisi dengan metode yang diterapkan. Hal itu dapat dilihat pada nilai siswa yang mengalami peningkatan pada Siklus II.

Secara rinci peneliti menyajikan hasil pembelajaran pada Siklus II. Rincian selengkapnya tentang hasil pembelajaran yang dilaksanakan pada Siklus II sebagai berikut. Siswa yang memperoleh nilai dengan rentang dibawah 60 sebanyak 0 siswa. Rentang nilai 60 s.d. 70 sebanyak 2 siswa, dan rentang 70 s.d. 100 sebanyak 30 siswa. Siswa yang memperoleh nilai dengan rentang diatas 73 sebanyak 25 siswa. Dengan nilai perolehan hasil belajar terendah sebesar 68 dan nilai tertinggi yaitu 100. Data tersebut menunjukkan bahwa hasil pembelajaran pada siklus II sudah mengalami peningkatan jika dibandingkan dengan pembelajaran pada fase Siklus I

Untuk mengetahui perbandingan hasil pembelajaran yang meliputi nilai siswa dan persentase ketuntasan hasil belajar siswa, peneliti akan menyajikan sebuah tabel yang berisi perbandingan nilai siswa dan ketuntasan hasil belajar siswa pada pembelajaran prasiklus, Siklus I, dan Siklus II .

Tab el 7 Perbandingan Nilai Ulangan Harian Siswa dan Ketuntasan Hasil Belajar Siswa pada Kondisi awal, Siklus I, dan Siklus II

\begin{tabular}{|c|c|c|c|c|}
\hline No & $\begin{array}{l}\text { Rentang } \\
\text { Nilai }\end{array}$ & $\begin{array}{l}\text { Frekuen } \\
\text { si Pra } \\
\text { Siklus }\end{array}$ & $\begin{array}{l}\text { Freku } \\
\text { ensi } \\
\text { Siklus } \\
\text { I }\end{array}$ & $\begin{array}{l}\text { Frek } \\
\text { uens } \\
\text { i } \\
\text { Sikl } \\
\text { us II }\end{array}$ \\
\hline 1 & dibawah 60 & 2 & 0 & 0 \\
\hline 2 & 60 s.d. 69 & 15 & 10 & 2 \\
\hline 3 & 70 s.d. 79 & 7 & 12 & 18 \\
\hline 4 & 80 s.d. 89 & 8 & 8 & 8 \\
\hline 5 & 90 s.d. 100 & 0 & 0 & 4 \\
\hline 6 & $\begin{array}{c}\text { Jumlah } \\
\text { nilai }\end{array}$ & 2252 & 2312 & 2524 \\
\hline 7 & Rata-rata & 70 & 72 & 79 \\
\hline 8 & KKM & 73 & 73 & 73 \\
\hline 9 & Tuntas & 13 & 20 & 25 \\
\hline 10 & $\begin{array}{l}\text { Tidak } \\
\text { tuntas }\end{array}$ & 19 & 12 & 7 \\
\hline
\end{tabular}

Sumber: penelitian 2020. 
Dari tabel 7 tersebut dapat diketahui bahwa pada pembelajaran Siklus II telah terjadi peningkatan hasil belajar siswa. Peningkatan tidak hanya pada rata-rata nilai siswa tetapi juga pada persentase ketuntasan hasil belajar siswa. Rata-rata nilai siswa pada prasiklus adalah 70 sedangkan pada Siklus I adalah 72. Peningkatan nilai rata-rata siswa dari prasiklus ke Siklus I adalah 2. Nilai ratarata siswa pada Siklus II adalah 79. Jadi, peningkatan nilai siswa dari Siklus I ke Siklus II adalah sebesar 7 poin. Ketuntasan hasil belajar siswa pada prasiklus adalah $41 \%$, sedangkan pada Siklus I adalah $62 \%$. Peningkatan persentase hasil belajar siswa dari prasiklus ke Siklus I adalah $21 \%$. Persentase ketuntasan hasil belajar siswa pada Siklus II adalah $78 \%$. Jadi, peningkatan persentase hasil belajar siswa dari Siklus I ke Siklus II adalah sebesar $16 \%$.

Diskripsi hasil pembelajaran siswa kelas VIII-H Semester Genap tahun pelajaran 2019/2020 SMP Negeri 1 Jaten dapat dilihat pada grafik berikut.

Grafik 3 Nilai Ulangan Harian Siswa Kondisi Awal, Siklus I dan Siklus 2

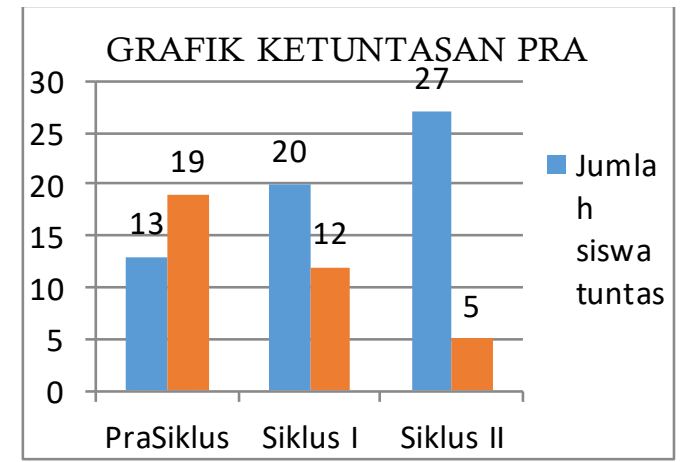

Sumber: penelitian 2020

\section{Pembahasan Antar Siklus}

Tindakan siklus I dan II adalah suatu kegiatan yang dilakukan peneliti setelah menerapkan pembelajaran model kooperatif kata konsep dalam pembelajaran memahami materi berbicara. Kegiatan tindakan siklus I dilakukan untuk mengetahui kemampuan awal siswa dalam memahami materi. Kegiatan tindakan ini diikuti oleh seluruh siswa kelas
VIII-H yang berjumlah 32 siswa. Hasil dari kegiatan tindakan siklus I dan II ini berupa data tes. Data tersebut dijelaskan lebih rinci dalam hasil tes tindakan siklus I dan II pada tabel berikut:

Tabel 8 Hasil Belajar siswa Selama Proses pembelajaran siklus I - Siklus II

\begin{tabular}{cccc}
\hline Aspek & $\begin{array}{c}\text { Pra } \\
\text { Siklus }\end{array}$ & Siklus I & $\begin{array}{c}\text { Siklus } \\
\text { II }\end{array}$ \\
\hline $\begin{array}{c}\text { Nilai } \\
\text { Tertinggi }\end{array}$ & 88 & 8 & 100 \\
$\begin{array}{c}\text { Nilai } \\
\text { Terendah }\end{array}$ & 52 & 60 & 67 \\
Rata-rata & 70 & 72 & 79 \\
$\begin{array}{c}\text { Ketuntasan } \\
\text { Klasikal }\end{array}$ & 41 & 62 & 78 \\
\hline
\end{tabular}

Sumber: penelitian 2020

Hasil belajar siswa meliputi rata-rata kelas, ketuntasan belajar individual dan ketuntasan belajar secara klasikal. Peningkatan pemahaman siswa sangat dipengaruhi keaktifan dan keterlibatan siswa dalam pembelajaran. Keaktifan dan keterlibatan siswa dalam proses pembelajaran merupakan salah satu faktor pendukung keberhasilan belajar.

Meningkatnya hasil belajar siswa dari siklus I ke siklus II menunjukkan terjadinya peningkatan pemahaman terhadap materi yang dipelajari. Pemahaman pada siswa mulai menunjukkan peningkatan yang signifikan. Hal ini menunjukkan bahwa metode pembelajaran dengan model kooperatif mampu meningkatkan hasil belajar siswa. Akan tetapi, walaupun hasil belajar pada siklus I meningkat, namun peningkatan ini belum optimal karena belum sesuai dengan indikator keberhasilan yang diharapkan, yaitu siswa yang memperoleh nilai $\geq 73$ kurang dari $70 \%$.

Pada siklus I, setelah mengalami tindakan dengan menggunakan pembelajaran model kooperatif, terjadi peningkatan hasil tes yang dilakukan oleh peneliti. Nilai terendah siswa adalah pada angka 70 . Hal ini menunjukkan peningkatan hasil belajar siswa dari pra siklus sebesar 52. Nilai tertinggi yang 
diraih siswa pada siklus I adalah 88. Nilai ratarata akhir pada siklus I menjadi 72, dan tercatat sebanyak 20 siswa telah melampaui nilai 73 sebagai batas KKM. Artinya peningkatan pemahaman materi dengan proses pembelajaran model kooperatif ini mulai dirasakan manfaatnya bagi siswa. Namun masih ada 38\% (12 siswa) yang belum tuntas KKM. Hal ini berarti belum memenuhi standart klasikal minimal ketuntasan klasikal. Untuk itu peneliti, melakukan siklus yang ke II.

Pada awal siklus I ini, peneliti menemukan beberapa catatan lapangan yang menunjukkan peningkatan hasil belajar siswa dari proses belajar dengan menggunakan metode pembelajaran model kata konsep dibanding sebelum adanya tindakan. Meskipun masih ditemukan beberapa siswa yang kurang aktif, namun paling tidak aktivitas belajar di dalam kelas terlihat lebih hidup dan peran serta siswa sebagai subyek penelitian semakin terasa.

Pada siklus II, setelah mendapatkan penguatan dan bimbingan yang lebih intensif pada saat melaksanakan dalam pembelajaran, didapatkan hasil yang sangat memuaskan yang didapatkan dari hasil belajar siswa. Hasil tes yang diperoleh oleh kelas penelitian ini menunjukkan efek dan manfaat metode belajar model kata konsep benar-benar telah dirasakan manfaatnya oleh para siswa. Hal tersebut ditunjukkan seperti terlihat pada tabel diatas.

Pada siklus II ini, peningkatan hasil belajar ditunjukkan adanya peningkatan hasil tes akhir siklus II. Nilai terendah siswa masih ada yang mendapatkan nila dibawah KKM sebanyak 7 siswa dan nilai tertinggi siswa mencapai angka 100. Dan rata-rata kelas pada tiap aspek sudah melampaui angka ketuntasan minimal. Dari 32 siswa yang belajar dalam kelas, 27 anak telah mencapai kriteria ketuntasan minimal (KKM). Hal itu berarti ketercapaian ketuntasan klasikal mencapai $70 \%$. Dengan begitu kriteria ketuntasan klasikal telah tercapai.

Peningkatan keaktifan siswa dari siklus I menyebabkan hasil belajar siswa pada siklus II juga cenderung meningkat. Peningkatan rata- rata kelas dan jumlah siswa yang belajar tuntas ini menunjukkan bahwa pemahaman siswa terhadap materi pembelajaran meningkat. Pembelajaran dengan metode crossword puzzle mempunyai beberapa kelebihan.

Kelebihan dari metode pembelajaran ini adalah siswa dilibatkan untuk turut berpikir sehingga emosi siswa dapat terlibat langsung dalam proses pembelajaran, meningkatkan keterampilan siswa melalui suatu kegiatan, dapat mengamati suatu proses/kejadian dengan sendirinya, sehingga akan memperkaya pengalaman dan meningkatkan serta membangkitkan rasa ingin tahu. Siswa akan lebih memahami sesuatu yang bersifat abstrak dan lebih mampu mengingat dalam jangka waktu yang relatiflebih lama. Kelebihan model kegiatan dengan berlatih atau praktek cenderung menggali pengetahuan siswa dan menarik minat siswa dalam membangun pengetahuannya.

Hal ini menunjukkan bahwa siswa yang diajar dengan menggunakan metode pembelajaran dengan metode crossword puzzle terdapat peningkatan hasil belajar yang signifikan. Proses belajar mengajar selama siklus II masih terdapat kekurangan. Kendala yang dihadapi adalah dari dalam diri siswa, yaitu faktor psikis. Hal ini dapat diatasi dengan terampilnya guru dalam memotivasi dan menumbuhkan suasana belajar yang menyenangkan. Ketuntasan belajar klasikal pada siklus II sudah melebihi $70 \%$, hal ini berarti indikator kinerja untuk peningkatan persentase siswa yang memperoleh KKM 73 atau jumlah siswa yang belajar tuntas meningkat menjadi $\geq 70 \%$ sudah tercapai.

\section{Keaktifan Siswa}

Kegiatan pembelajaran dengan menggunakan model ini akan meningkatkan motivasi dan hasil belajar siswa. Penggunaan model pembelajaran menyebabkan proses belajar mengajar menjadi menarik, dapat menumbuhkan minat siswa untuk menerima pelajaran dan dapat diaplikasikan dalam berbagai pendekatan pembelajaran. 
Siswa yang belum aktif dalam pembelajaran diduga karena mereka belum terbiasa dengan kegiatan pembelajaran melalui model kata konsep , adanya perasaan malu dan tidak percaya diri, kurang tertarik saat kegiatan diskusi, kurang berani dalam presentasi, dan masih kurang mampu dalam menjawab pertanyaan maupun bertanya kepada guru atau teman.

Saat kegiatan berlangsung, siswa sangat ramai sehingga guru perlu berkali - kali memperingatkan siswa. Keramaian yang terjadi karena siswa lebih banyak bersendau gurau dengan temannya dibandingkan bekerja dan berlatih dalam kelompoknya. Seringkali muncul pertanyaan - pertanyaan dari siswa yang tidak memberikan kata kunci yang tepat, hal ini disebabkan selain karena penguasaan pada materi masih rendah juga karena siswa masih kurang serius dalam melaksanakan kegiatan ini, akibatnya penggunaan waktu menjadi kurang efektif. Penggunaan waktu yang tidak efektif oleh siswa terjadi karena siswa bersenda gurau dan bermain sendiri. Berdasarkan refleksi pada siklus I, ditemukan adanya kekurangan pada siswa yaitu kurang aktifnya siswa saat proses pembelajaran. Kekurangan ini dapat diperbaiki dengan cara siswa harus lebih mengerti kegiatan pembelajaran melalui model kata konsep seperti ini, siswa harus berusaha lebih aktif dalam proses pembelajaran sehingga dapat menyesuaikan dengan apa yang diinginkan guru, demikian juga guru harus lebih mampu mengelola kelas dan memotivasi siswa lebih baik.

Pada siklus II tingkat keaktifan siswa semakin meningkat. Siswa yang aktif dalam pembelajaran sudah hampir merata. Siswa lebih aktif dan serius dalam melakukan kegiatan ini. Siswa bekerja sama dalam kelompok melalui pengamatan, baik secara langsung maupun tidak langsung dengan membangun pengetahuannya dan lebih mudah memahami konsep-konsep yang dipelajarinya. Siswa semakin antusias dalam melaksanakan kegiatan. Bahkan ada beberapa kelompok yang tampak memberikan variasi pemecahan masalah rujukan yang lebih berkembang dibanding pada saat siklus I. Pada siklus II ini keberhasilan peningkatan persentase siswa yang terlibat aktif dalam proses pembelajaran telah tercapai.

\section{Refleksi}

Pada hasil tes pratindakan, menunjukkan bahwa metode belajar konvensional tidak membantu siswa dalam mencapai kemampuan berbicara. Hal tersebut ditunjukkan dengan hasil dari test pratindakan yang diperoleh oleh siswa masih banyak siswa yang belum memenuhi nilai ketuntasan minimal yang ditetapkan. Hal tersebut mendorong peneliti untuk melakukan tindakan penelitian kelas.

Pada siklus I, pembelajaran dilaksanakan dengan menggunakan metode belajar model crossword puzzle. Pada awalnya siswa masih merasa canggung dan aneh terhadap penggunaan metode ini, dari temuan lapangan didapat siswa masih belum mampu mengkomunikasikan proses belajar dengan teman sebayanya. Ada beberapa siswa yang merasa malu untuk melakukan presentasi kepada teman yang lain. Dan masih ditemukan kalimat yang belum tepat untuk menjelaskan seseuatu hal kepada anggota kelompok yang lain sehingga memunculkan masalah bagi anggota kelompok tersebut. Meskipun masih banyak ditemukan kekurangan pada tahap kegiatan siklus I ini, namun manfaat sudah dapat dirasakan oleh sebagian besar siswa, selain proses pembelajaran lebih hidup dan aktif, nilai akhir tes siklus I juga menunjukkan peningkatan yang sangat baik.

Pada siklus II, pelaksanaan metode pembelajaran model crossword puzzle mulai dapat dilaksanakan dengan baik dan sistematis oleh para siswa. Rasa tanggung jawab terhadap diri sendiri dan kepada kelompok besar menjadi motivasi tersendiri bagi siswa. Dengan sedikit bimbingan dari peneliti, kegiatan pada tahap ini sudah dapat berjalan sesuai dengan harapan yang diinginkan. Pelaksanaan metode pendekatan 
crossword puzzle terlihat meningkatkan aktifitas belajar siswa, keberanian untuk berkomunikasi dengan teman anggota kelompok mulai tampak, setiap siswa memiliki kemauan untuk menjadi ahli dalam materi yang mereka diskusikan dalam kelompok sebelumnya. Hasil tes akhir siklus II memberikan gambaran bahwa metode model pendekatan kata konsep meningkatkan pemahaman. Dari 32 siswa dalam kelas, sebesar $78 \%$ siswa atau 25 anak telah mencapai nilai $\mathrm{KKM}$

\section{SIMPULAN}

Berdasarkan hasil penelitian dan pembahasan yang telah diuraikan, dapat disimpulkan bahwa melalui metode pembelajaran dengan model pembelajaran crossword puzzle di kelas VIII-H SMP Negeri 1 Jaten keaktifan dan hasil belajar siswa dapat meningkatkan hasil belajar siswa dari rata-rata kelas 70 menjadi 78 dengan ketuntasan klasikal $41 \%$ menjadi $78 \%$.

Untuk itu, hendaknya guru menerapkan model kooperatif pada materi-materi yang lainnya, karena metode pembelajaran yang divariasikan dengan kegiatan model kooperatif memudahkan siswa dalam memahami materi yang dipelajari. Perlu dilakukan sosialisasi terlebih dahulu tentang langkah-langkah metode pembelajaran yang divariasikan dengan kegiatan pada siswa sebelum diterapkan dalam pembelajaran agar proses pembelajaran dapat berjalan dengan lancar. Perlu diupayakan pengelolaan kelas yang baik oleh guru saat proses pembelajaran berlangsung sehingga siswa benar-benar terlibat dalam proses pembelajaran.

\section{DAFTAR PUSTAKA}

Arikunto, Suharsimi. 2006. Prosedur Penelitian Suatu Pendekatan Praktek. Jakarta: Rineka Cipta.

Arikunto, Suharsimi, dkk. 2006. Penelitian Tindakan Kelas. Jakarta: Bumi Aksara.
Aqib, Zainal. 2006. Penelitian Tindakan Kelas bagi Pengembangan Profesi Guru. Bandung: Yrama Widya.

BSNP. 2009. Peraturan Menteri Pendidikan Nasional No. 22 Tahun 2006 tentang Standar Isi. Jakarta: Depdiknas.

Dimyati dan Mudjiono. 2002. Belajar dan Pembelajaran. Jakarta: Rineka Cipta

Fajar, Arnie. (2009). Portofolio Dalam Pelajaran IPS. Bandung: PT Remaja Kosdakarya.

Sanjaya, Wina. 2007. Strategi Pembelajaran (Berorientasi Standar Proses Pendidikan). Jakarta: Prenada Media Group.

Slameto, 2010, Belajar dan Faktor-Faktor Yang Mempengaruhi, Jakarta: Rineka Cipta.

Hamdani. 2011. Strategi Belajar Mengajar.Bandung: CV Pustaka Setia

Hamalik, Oemar. 2011. Kurikulum dan Pembelajaran. Jakarta: Bumi Aksara.

Mulyasa, E. 2003. Menjadi Guru Profesional. Bandung: Remaja Rosdakarya

Sari. 2013. Peningkatan Pemahaman Konsep Koperasi dengan Menggunakan Metode Pembelajaran Crossword Puzzle. Skripsi: Universitas Negeri Sebelas Maret

Silberman, Mel. 2009. Active Learning: 101 Strategi Pembelajaran Aktif. Yogyakarta: Pustaka Insan Madani.

Sudjana, Nana. 2014. Penilaian Hasil Proses Belajar Mengajar. Bandung: PT Remaja Rosdakarya.

Slameto. 2010. Belajar dan faktor-faktor yang mempengaruhinya, Jakarta: PT Rineka Cipta

Slavin, Robert E. 2009. Cooperative Learning. Bandung: Nusa Media 
Suprijono, Agus. 2011. Cooperative Learning Teori \& Aplikasi PAIKEM. Yogyakarta: Pustaka Belajar.

Wijiastuti, Retno. 2013. Keefektifan Strategi Crossword PuzzlePada Hasil Belajar IPS. Skripsi. Universitas Negeri Semarang.

Susilo, A., Rumende, C. M., Pitoyo, C. W., Santoso, W. D., Yulianti, M., Herikurniawan, H., Sinto, R., Singh, G., Nainggolan, L., Nelwan, E. J., Chen, L.
K., Widhani, A., Wijaya, E., Wicaksana, B., Maksum, M., Annisa, F., Jasirwan, C. O. M., \& Yunihastuti, E. (2020). Coronavirus Disease 2019: Tinjauan Literatur Terkini. Jurnal Penyakit Dalam Indonesia, $7(1)$ https://doi.org/10.7454/indi.v7i1.415

Yanuarita, Intan., dan Wiranto. 2018. Mengenal Media Sosial agar Tak Menyesal. Jakarta: Badan Pengembang dan Pembinaan Bahasa. 